\title{
Management of Stripped Mealybug in Yam Bean
}

\author{
M. Nedunchezhiyan*, S. K. Jata, Kalidas Pati, V.B.S. Chauhan and V. Bansode \\ Regional Centre of ICAR-Central Tuber Crops Research Institute, \\ Dumuduma, Bhubaneswar-751 019, Odisha, India \\ *Corresponding author
}

\section{A B S T R A C T}

Keywords

Ferrisia virgata, Infestation, Pachyrrhizus erosus, Seed yield

Article Info

Accepted:

11 June 2020

Available Online:

10 July 2020
On $5^{\text {th }}$ November 2011, stripped mealybug (Ferrisia virgata Cockerrel) was first noticed infesting on yam bean (Pachyrrhizus erosus (L) Urban) seed crop at the Regional Centre of Central Tuber Crops Research Institute, Bhubaneswar, Odisha, India. Analyses of weather data revealed that higher maximum and lower minimum temperatures coupled with wide diurnal variation of temperature from October to December during the year 2011 compared to decennial mean was observed. Further, a sharp decline in mean relative humidity and rainfall was observed between October and December during 2011 compared to decennial mean. It was observed $38.3 \%$ yam bean seed yield loss due to stripped mealybug infestation.

\section{Introduction}

Yam bean (Pachyrhizus erosus (L) Urban) otherwise called potato bean is grown for its starchy root. In India, it is called 'Mishrikkand' in Bihar, 'Kesaru' in Eastern Uttar Pradesh and 'Sankalu' in Orissa, West Bengal and Assam. Yam bean belongs to the family Leguminaceae and sub family Fabaceae. This climbing leguminous herb has coarse hairy vine with. The leaves are alternate trifoliate large with toothed leaflets. The tap root of yam bean developed into turnip or conical shaped tubers. The starchy conical or turnip shaped fleshy tubers are eaten. High sugar content in tubers imparts sweet taste when eaten raw. The fresh tubers are crisp juicy and refreshing flesh used as salad and can also be made into chips.

The over matured tubers become fibrous, hence unsuitable for consumption. Normally the crop (yam bean) which is grown for tuber purpose will not be allowed to flower. Tuber bulking was not found in flowering plants. However, seed crops are allowed to flower, and fruiting and seed setting. The crop is harvested after pods are fully matured and dried. The duration of seed crops are 150-160 days, which is 30-45 days more than crops grown for tuber purpose. 
Mealybugs (Hemiptera: Pseudococidae) are small, soft bodied insects that feed by sucking plant sap. They cause considerable economic damage to agricultural and horticultural plants (Miller et al., 2002, 2005; Nedunchezhiyan et al., 2011; Silva-Torres et al., 2013). Mealybug damages the crops by direct sap sucking (Nedunchezhiyan et al., 2011) and injection of toxins, as well as indirectly by honeydew contamination and associated sooty mold growth that decreases photosynthesis (Mibey, 1997; Oliveira et al., 2014), and occasionally from the effects of transmitted plant viruses (Bhat et al., 2003; Ben-Dov, 2005). Feeding damage may cause leaf yellowing, defoliation, reduced plant growth and death of plants. Even if plant damage is not apparent, the mere presence of mealybugs can be a quarantine concern, adding to costs of production to prevent or eliminate their presence on plants and produce. Stripped mealybug (Ferrisia virgata Cockerrel) infests on many agriculturally important families such as Cucubitaceae, Fabaceae, Musaceae, Myrtaceae, Arecaceae, Rubiaceae, Rutaceae and Solanaceae (Ben-Dov, 2005; Halima et $a l .$, 2018). Culik et al., (2006) reported that mango, papaya and pineapple were also potential host crops. In India, Gaware et al., (2011) found $F$. virgata infestation on guova (Psidium guajava) in Maharastra. Bhat et al., (2003) reported that $F$. virgata was associated in transmitting badnavirus in black pepper (Piper nigrum L.) in West coast of India. On $5^{\text {th }}$ November 2011, F. virgata was first noticed infesting on yam bean seed crop in Bhubaneswar, India, though it was not reported on yam bean in India and elsewhere earlier. Seven days after appearance of mealy bug, an investigation was carried out to manage the mealybug menace.

\section{Materials and Methods}

At the Regional Centre of ICAR-Central Tuber Crops Research Institute $\left(20^{\circ} 14^{\prime} 50^{\prime \prime} \mathrm{N}\right.$ and $85^{\circ} \quad 47^{\prime} \quad 06^{\prime \prime}$ E), Dumuduma, Bhubaneswar, Odisha, India, yam bean seed production programme was under taken during 2011 in 0.2 ha under rainfed conditions. The top $0-15 \mathrm{~cm}$ soil depth of the yam bean seed production field was sandy clay loam with bulk density of $1.52 \mathrm{~g} \mathrm{~cm}^{-3}$. The soil was acidic ( $\mathrm{pH}$ 5.8), low in available $\mathrm{N}\left(215 \mathrm{~kg} \mathrm{ha}^{-1}\right), \mathrm{P}\left(17 \mathrm{~kg} \mathrm{ha}^{-1}\right)$ and $\mathrm{K}(195 \mathrm{~kg}$ $\left.\mathrm{ha}^{-1}\right)$. The crop was sown on $15^{\text {th }}$ July 2011 at $30 \mathrm{~cm}$ spacing between plants on raised bed formed $75 \mathrm{~cm}$ apart. A basal dose of $\mathrm{N}_{-} \mathrm{P}_{2} \mathrm{O}_{5-}$ $\mathrm{K}_{2} \mathrm{O} 40-60-40 \mathrm{~kg} / \mathrm{ha}$ was applied. Thirty days after planting, the crop was top dressed with $\mathrm{N}-\mathrm{K}_{2} \mathrm{O} 40-40 \mathrm{~kg} / \mathrm{ha}$. Two hand-weeding at 30 and 60 days after planting was carried out.

Five days after mealybug appearance, the field was divided into five parts (strips) each having $400 \mathrm{~m}^{2}$. The following treatments were imposed: monocrotophos, acephate, water spray and control. Two spraying was given. The first spraying was on $12^{\text {th }}$ November 2011 and the second was on $22^{\text {nd }}$ November 2011. In each treatment, randomly $1 \mathrm{~m}^{2}$ area in five locations was marked for sampling. These five locations were considered as replications while analyzing the data statistically. The crop was harvested 150 days after sowing.

\section{Results and Discussion}

On $5^{\text {th }}$ November 2011, stripped mealybug ( $F$. virgata) was first noticed infesting on yam bean seed crop. At the time of infestation the crop was in fruiting stage. The plants were full of immature young pods. The appearance of live $F$. virgata was distinctive: adult females generally appear grayish covered with white powdery wax and a pair of dark stripes (or rows of spots) dorsally (as the common name implies), with the body relatively elongated, tapering posteriorly and terminating in a pair of long wax filaments (Photo 1). Legs were dark brown. The initial 
infestation was found on lower side of the bottom leaves. Soon it was seen on growing points and young immature pods (Photo 2). Initially the infested parts were full of white mealy substances. Later, the apical meristem and other growing parts turned into black. The young pods were curled inwards and blackened. The other infested parts also slowly blackened and dried. At maturity pods from $1 \mathrm{~m}^{2}$ area of infected and uninfected field was collected for assessing seed yield. Seven numbers of samples in each category (replications) was collected and the data was subjected to paired t-test.

Earlier $F$. virgata was not reported on yam bean in India. This might be due to climate change. Hence, weather data of temperature, relative humidity and rainfall for the period of 2001-2011 was analysed. Weather parameters of 2011 were compared with decennial average (2001-2010). Changes in climate may result in changes in geographical distribution, changes in population growth rates, increases in the number of generations and changes in crop-pest synchrony (Porter et al., 1991). Temperature is one of the most important and critical abiotic factors that can affect insect development as well as the population dynamics of insect pests (Huffaker et al., 1999; Amarasekare et al., 2008). The maximum temperature between October and December was found higher during 2011 compared to decennial average (2001-2010) (Figure 1). During the year 2011, November month recorded $1.6^{\circ} \mathrm{C}$ higher maximum temperature compared to decennial mean for the corresponding month. High temperature shortens the life cycle; nymphs develop rapidly and become adults 2-3 times sooner than low temperatures (Amarasekare et al., 2008). The minimum temperature from June to December during 2011 was observed lower than decennial mean (Figure 1). It was lesser by $0.2-1.3^{\circ} \mathrm{C}$. The year 2011 November recorded $1.3^{\circ} \mathrm{C}$ lesser minimum temperature than decennial mean for the corresponding month.

Table.1 Rainfall (mm) during the year 2011 and decennial mean (2001-2010)

\begin{tabular}{|l|c|c|}
\hline Months & Decennial & $\mathbf{2 0 1 1}$ \\
\hline June & 218.1 & 180.3 \\
\hline July & 348.0 & 361.7 \\
\hline August & 366.5 & 419.5 \\
\hline September & 324.9 & 290.0 \\
\hline October & 178.6 & 57.0 \\
\hline November & 27.4 & 0 \\
\hline December & 6.4 & 0 \\
\hline
\end{tabular}

Table.2 Effect of $F$. virgata infestation on yield attributes and seed yield of yam bean

\begin{tabular}{|c|c|c|c|c|}
\hline Treatment & No. of pods $/ \mathrm{m}^{2}$ & No. of seeds/pod & $\begin{array}{c}\text { 100-seed weight } \\
\text { (g) }\end{array}$ & $\begin{array}{c}\text { Seed yield } / \mathbf{m}^{2} \\
(\mathrm{~g})\end{array}$ \\
\hline Infested field & 54 & 2.1 & 18.4 & 52.2 \\
\hline Uninfested field & 85 & 4.9 & 20.7 & 84.6 \\
\hline $\begin{array}{l}\text { Paired t-test } \\
(P=0.05)\end{array}$ & Sig. & Sig. & Sig. & Sig. \\
\hline
\end{tabular}

Sig. = Significant 
Photo.1 Stripped mealy bug infestation on leaf

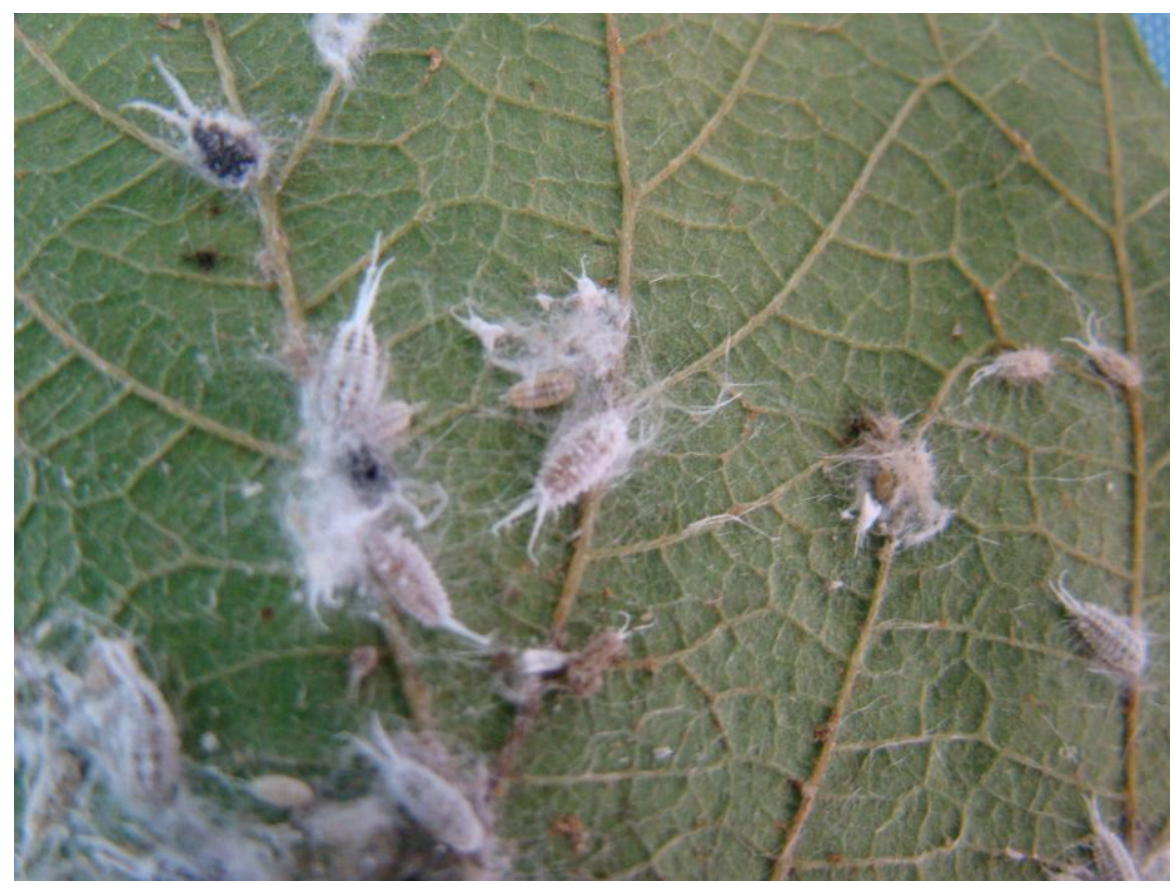

Photo.2 Stripped mealy bug infestation on pods

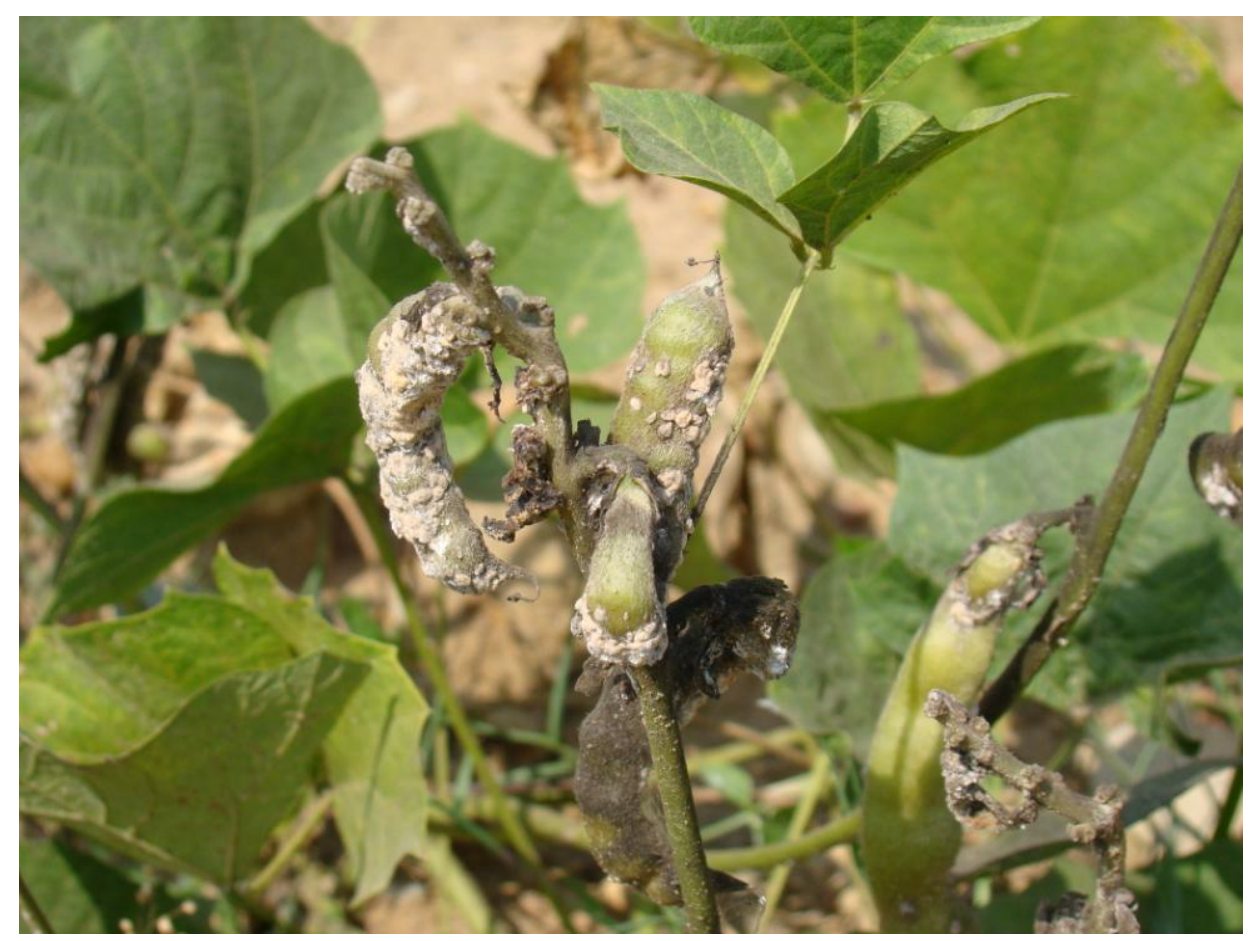


Fig.1 Maximum, minimum and diurnal variation of temperatures $\left({ }^{\circ} \mathrm{C}\right)$ during 2011 and decennial mean (2001-2010)

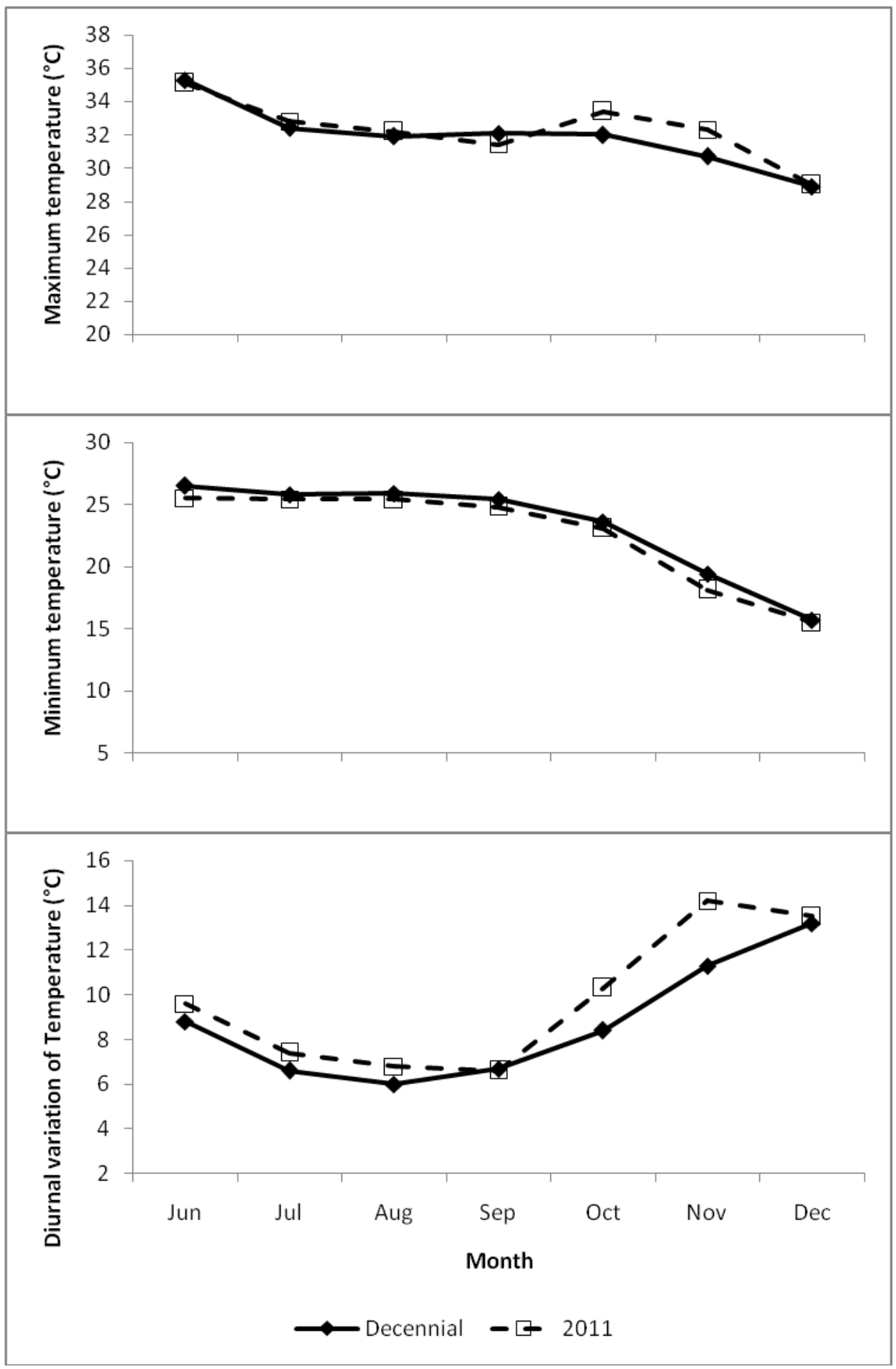


Fig.2 Forenoon, afternoon and mean relative humidity (\%) during 2011 and decennial mean (2001-2010)

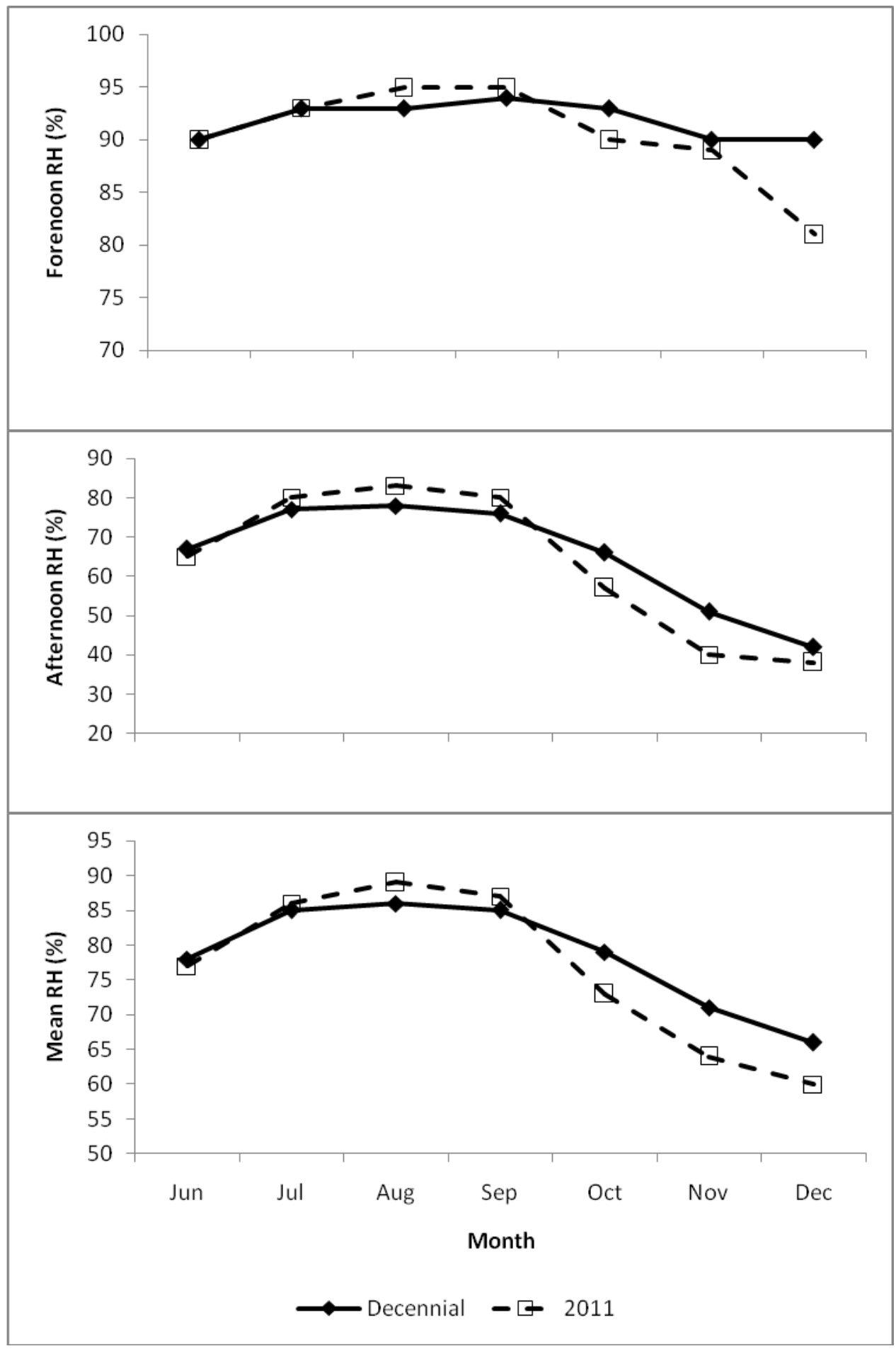

Analyses of diurnal variation of temperature revealed that during the year 2011 higher diurnal variation was observed between June and December compared to decennial mean except September (Figure 1). During October and November 2011, the diurnal variation of 
temperature was 1.9 and $2.9^{\circ} \mathrm{C}$ higher than decennial mean for the corresponding months, respectively. Higher maximum temperature, lower minimum temperature and wider diurnal variation of temperature during 2011 might be responsible for out break of stripped mealybug on yam bean. The timing of attack by pest insects depends mainly on temperature (Finch et al., 1996). Analyses of relative humidity revealed that during the year 2011 between October and December, a sharp decline in mean relative humidity compared to decennial mean (Figure 2). This was due to lower afternoon relative humidity. Further a sharp decline in rainfall was observed between October and December during 2011 compared to decennial mean (Table 1). During the year 2011 October month received just $57 \mathrm{~mm}$ and it was $1 / 3^{\text {rd }}$ of decennial mean. No rainfall was received during November and December in the year 2011. Santanu and Jha (2008) and Eid et al., (2011) reported that pest population was positive correlation with relative humidity and rainfall. Dry weather due to low rainfall, low relative humidity and high variation in maximum and minimum temperature (diurnal variation) during the year 2011 might be responsible for the outbreak of $F$. virgata on yam bean.

Seven samples each from infested and uninfested area $\left(1 \mathrm{~m}^{2}\right.$ area each sample) were taken at harvest for comparison of possible impact on yam bean seed yield and presented in the Table 2. A drastic reduction of 36.5, $57.1,11.1$ and $38.3 \%$ number of $\operatorname{pods} / \mathrm{m}^{2}$, number of seeds/pod, 100-seed weight and seed yield $/ \mathrm{m}^{2}$, respectively was observed in stripped mealy bug infested field.

\section{Acknowledgement}

The authors acknowledge the financial support received from the Project Coordinator, All India Co-ordinated Research Project on Tuber Crops, ICAR-CTCRI,
Thiruvananthapuram and facilities provided by the Director, ICAR-Central Tuber Crops Research Institute, Thiruvananthapuram.

\section{References}

Amarasekare, K.G., Chong, J.H., Epsky, N.D. and Mannion, C.M. 2008. Effect of temperature on the life history of the mealybug Paracoccus marginatus (Hemiptera: Pseudococcidae). Ecol. Behavior, 101(6):1798-1804.

Ben-Dov, Y. 2005. ScaleNet, Pseudococcidae catalogue.

http://www.sel.barc.usda.gov/ scalenet/scalenet.htm. ferrisia virgata: http://www.sel.barc.usda.gov/ catalogs/pseudoco/ ferrisiavirgata.htm.

Bhat, A.I., Devasahayam, S., Sarma, Y.R. and Pant, R.P. 2003. Association of a badnavirus in black pepper (Piper nigrum L.) transmitted by mealybug (Ferrisia virgata) in India. Current Sci., 84:1547-1550.

Culik, M.P., Martins, D.S. and Gullan, P.J. 2006. First record of two mealybug species in Brazil and new potential pests of papaya and coffee. J. Insect Sci., 6(23):6. available online: insectscience.org/6.23.

Eid, M.A., El Shabrawy, H.A. and Yakoub, R.S. 2011. Effect of some weather factors on pink sugarcane mealybug, Saccharicoccus sacchari Ckll. (Homoptera: Pseudococcidae). Academic J. Entomol., 4(2):34-40.

Finch, S., Collier, R.H. and Phelps, K. 1996. A review of work done to forecast pest insect attacks in UK horticultural crops. Crop Protection, 15(4):353-357.

Gaware, K.H., Jondhale, A.S. and Apparao, B.J. 2011. Biological control of mealybug (Ferrisia virgata C.) with the help of Balanites aegyptiaca Delli. A Quarterly J. Life Sci., 8(4): 413-414.

Halima, M.K.B., Mdellel, L., Zouari, S. and 
Germain, J.F. 2018. Ferrisia virgata Cockerell (Hemiptera: Pseudococcidae): first record in Tunisia. Bulletin OEPP/EPPO Bulletin, 48(3): 583-585.

Huffaker, C., Berryman, A. and Turchin, P. 1999. Dynamics and regulation of insect populations. In Ecological Entomology (eds. Huffaker, C. B. and Gutierrez, A.P.), $2^{\text {nd }}$ edition, Wiley, New York, pp. 269-305.

Mibey, R,K. 1997. Sooty moulds. In Soft Scale Insects: their Biology, Natural Enemies and Control (eds. Ben Dov, Y. and Hodgson, C. J.), Elsevier, Amsterdam and New York, pp. 275290.

Miller, D.R., Miller, G.L. and Watson, G.W. 2002. Invasive species of mealybugs (Hemiptera: Pseudococcidae) and their threat to U.S. Agriculture. Proc. Entomol. Soc. Washington, 104:825836.

Miller, G.L., Miller, D.R., Limones, E.M., Gill, R.J., Carlson, R.W. 2005. The United States National Collection of Scale Insect Photographs. Available from:http://www.sel.barc.usda.gov:591/ scale_slide/slide_frame. htm.

Nedunchezhiyan, M., Jata, S.K., Ray, R.C. and Misra, R.S. 2011. Management of mealybug (Rhizoecus Amorphophalli) in elephant foot yam (Amorphophallus paeoniifolius). Exp. Agric. 47:717-728.

Oliveira, M.D., Silva-Torres, C.S.A., Torres, J.B. and Oliveira, J.E.M. 2014. Population growth and within-plant distribution of the striped mealybug Ferrisia virgata (Cockerell) (Hemiptera, Pseudococcidae) on cotton. Rev. Bras. entomol., 58(1), https://doi.org/10.1590/S008556262014000100012.

Porter, J.H., Parry, M.L. and Carter, T.R. 1991. The potential effects of climate change on agricultural insect pests. Agric. Forest Meteorol., 57(1-3):221240.

Santanu, G. and Jha, A.R. 2008. Scientific notes on morphological characters, crop loss assessment and seasonal abundance of sugarcane wooly aphid (Ceratovacuna lanigera Zehntener, Family: Aphididae, Order: Homoptera) in West Bengal. Co-op. Sugar, 39(8):37-43.

Silva-Torres, C.S.A., Oliveira, M.D. and Torres, J.B. 2013. Host selection and establishment of striped mealybug, Ferrisia virgata, on cotton cultivars. Phytoparasitica 41: 31-40.

\section{How to cite this article:}

Nedunchezhiyan, M., S. K. Jata, Kalidas Pati, V.B.S. Chauhan and Bansode, V. 2020. Management of Stripped Mealybug in Yam Bean. Int.J.Curr.Microbiol.App.Sci. 9(07): 13051312. doi: https://doi.org/10.20546/ijcmas.2020.907.150 